\title{
Long-term evaluation of the adequacy of habitual diets to provide protein needs of adult Nigerian men
}

\author{
By T. ATINMO, G. EGUN* AND C. M. F. MBOFUNG $\ddagger$ \\ Department of Human Nutrition, College of Medicine, University of Ibadan, \\ Ibadan, Nigeria
}

(Received 22 March 1988 - Accepted 20 May 1988)

\begin{abstract}
1. A continuous $40 \mathrm{~d}$ metabolic nitrogen balance study was conducted on twelve young men aged 25 (SD 2.6) years to evaluate the adequacy of a previously determined safe level of protein intake.

2. Subjects were fed on diets which they were habitually accustomed to and which provided a protein level of $0.75 \mathrm{~g}$ protein $(\mathrm{N} \times 6.25) / \mathrm{kg}$ body-weight per $\mathrm{d}$ as the safe level and an energy intake level of $0.2 \mathrm{MJ} / \mathrm{kg}$ bodyweight per $\mathrm{d}$. $\mathrm{N}$ balances, including an estimate for integumental losses as well as certain biochemical variables, were determined for the last $5 \mathrm{~d}$ of two consecutive $20 \mathrm{~d}$ diet periods.

3. Only two of the twelve subjects were observed to be in negative $\mathrm{N}$ balance during the final $5 \mathrm{~d}$ of the $40 \mathrm{~d}$ period. $\mathrm{N}$ balance was generally positive at 8.24 (SD 8.61 ) $\mathrm{mg} \mathrm{N} / \mathrm{kg}$ body-weight, thus confirming the adequacy of $0.75 \mathrm{~g}$ protein $/ \mathrm{kg}$ body-weight per $\mathrm{d}$ as a safe level of protein intake in the majority of the subjects.
\end{abstract}

Attempts have been made using different approaches to quantify the amount of nitrogen needed by man for growth and maintenance of health. Two physiological approaches were used by the Joint FAO/WHO ad hoc Expert Committee on Energy and Protein Requirements of man (World Health Organization, 1973): these are the factorial approach based on results from short-term, $\mathrm{N}$-free diets fed to young adults, and the approach based on the use of results from linear extrapolation of short-term $\mathrm{N}$ balance studies in young adults fed on graded levels of protein (Huang \& Lin, 1982).

It is now becoming clear that short-term $\mathbf{N}$ balance determinations alone may not provide an adequate measure of dietary protein needs or of changes in nutritional status. Measurement of $\mathrm{N}$ balance is simply an overall summation of body $\mathrm{N}$ change. It provides no information on the occurrence and significance of either beneficial or deleterious adaptations that may arise from possible alterations in the pattern of $\mathbf{N}$ distribution and metabolism within the body (Yoshimura, 1972). From this point of view, therefore, the use of $\mathrm{N}$ balance studies of longer duration seem more desirable and acceptable, as information derived from them would include the effect of any forms of adaptations not noticed in short-term studies, such as those recently used to determine the protein requirements of adult and young adult Nigerians (Atinmo et al. 1981, 1988). In the earlier study by Atinmo et al. (1981), the protein requirement of the subjects was estimated at $0.60 \mathrm{~g} / \mathrm{kg}$ bodyweight per d, while the safe level of protein intake was suggested to be $0.75 \mathrm{~g} / \mathrm{kg}$ body weight per $d$.

This safe level of protein intake was also obtained from the extrapolation of the results of an $\mathrm{N}$ balance study in young Nigerians using graded levels of protein intake (Atinmo et al. 1988). However, since this value in both cases was based on the results of short-term studies, further testing under free-living conditions and for a longer period was deemed necessary. The objective of the present study was to evaluate the adequacy of the safe level of protein intake $(0.75 \mathrm{~g} / \mathrm{kg}$ body-weight per d) in adult Nigerian men consuming their habitual diets containing this level of protein for a period of $40 \mathrm{~d}$.

Present addresses: *Department of Biochemistry, Lagos State University, Lagos, Nigeria. † Department of Food Science and Nutrition, ENSIAAC Ngaoundere University Centre, Ngaoundere, Cameroon.

$\ddagger$ For reprints. 


\section{MATERIALS AND METHODS}

Twelve young university men, between the ages of 22 and 29 years, participated in the study. All were free from any detectable medical or physical abnormalities. The initial characteristics of the subjects are shown in Table 1 . The subjects were studied under close supervision in their nearby hall of residence and were engaged in their normal routine of daily activities, which included their full academic schedule while maintaining a reasonable, constant level of physical activity.

Daily body-weights were recorded at 07.00 hours throughout the entire study period under standardized conditions (preprandial, post-voiding, and with light indoor clothing).

\section{Diets}

The composition of the diet, which was similar to the habitual diets of the subjects, is described by Atinmo et al. (1988). The basic formula was the same for all subjects. In order to meet individual energy requirements without increasing the protein level of the diet, the individual energy intake of $0.2 \mathrm{MJ} / \mathrm{kg}$ body-weight was met in each case by the addition or removal from the basic diet formula, of an extra energy source in the form of an orangeflavoured drink. The diet provided $0.75 \mathrm{~g}$ protein $/ \mathrm{kg}$ body-weight per $\mathrm{d}$ which was the safe level of protein estimated from a short-term $\mathrm{N}$ balance study by Atinmo et al. (1981). The diets were served in a meal pattern that was familiar to the subjects, i.e. meals at $07.00-08.00,13.00-14.00$ and $19.00-20.00$ hours.

Throughout the study, all subjects were required to adhere strictly to the experimental diets and not to eat anything outside the diets provided. For the purpose of exploring adaptations to the test protein level, the $40 \mathrm{~d}$ experimental period was divided into two consecutive $20 \mathrm{~d}$ diet periods for $\mathrm{N}$ balance studies.

The study plan was approved by the Ethical Committee of the College of Medicine and subjects signed consent forms.

\section{Sampling and measurement}

Daily urinary and faecal samples were collected as voided according to strict protocols and later analysed as in a previous study (Atinmo et al. 1985). The collection of the samples was done on days $16-20$ and $36-40$ of the study.

Fasting blood samples were drawn from the antecubital vein into heparinized tubes which were then centrifuged and analysed according to standard biochemical methods using specific reagent kits for each type of analysis. Sweat $\mathrm{N}$ losses were collected by the methods of Sirbu et al. (1967) and of Spence et al. (1972).

Anthropometric measurements to detect possible changes in body composition were made. These measurements included mid-arm muscle circumference and skinfold thicknesses at triceps, subscapular and suprailiac sites.

\section{$N$ balance}

$\mathrm{N}$ balance (mg N/kg body-weight per $\mathrm{d}$ ) was calculated from the analysed $\mathrm{N}$ intake, total daily urinary $N$ for the last $5 \mathrm{~d}$ of each $20 \mathrm{~d}$ period (UN) and total daily faecal $\mathrm{N}$ (estimated from the $5 \mathrm{~d}$ faecal pool, $\mathrm{FN}$ ). In addition a factor to allow for miscellaneous $\mathrm{N}$ losses through sweat was also included in the calculations.

\section{RESULTS}

A comparison of the body-weight of the subjects before and during each of the two dietary periods showed no significant difference (Table 2). Anthropometric measurements taken at the beginning, in the middle and at the end of the study (Table 3) also did not show any significant changes. 
Table 1. Characteristics of the adult Nigerian male subjects

\begin{tabular}{lcccc}
\hline \hline Subject & $\begin{array}{c}\text { Age } \\
\text { (years) }\end{array}$ & $\begin{array}{c}\text { Wt } \\
(\mathrm{kg})\end{array}$ & $\begin{array}{c}\text { Height } \\
(\mathrm{m})\end{array}$ & $\begin{array}{c}\text { BMR } \\
(\mathrm{MJ} / \mathrm{d})\end{array}$ \\
\hline M1 & 29 & 62.0 & 1.63 & 7.23 \\
M2 & 27 & 57.0 & 1.63 & 6.89 \\
M3 & 27 & 57.0 & 1.64 & 6.89 \\
M4 & 25 & 56.0 & 1.68 & 6.96 \\
M5 & 26 & 58.0 & 1.68 & 6.96 \\
M6 & 23 & 61.0 & 1.71 & 7.17 \\
M7 & 28 & 69.0 & 1.72 & 7.71 \\
M8 & 22 & 64.5 & 1.71 & 7.40 \\
M9 & 22 & 49.5 & 1.55 & 6.38 \\
M10 & 22 & 60.0 & 1.76 & 7.10 \\
M11 & 22 & 73.5 & 1.75 & 8.02 \\
M12 & 26 & 61.0 & 1.76 & 7.17 \\
Mean & 25 & 60.7 & 1.68 & 7.16 \\
SD & 2.6 & 6.3 & 0.68 & 0.42 \\
\hline \hline
\end{tabular}

BMR, basal metabolic rate calculated by the World Health Organization (1973) method.

Table 2. Body-weights $(\mathrm{kg})$ of twelve adult Nigerian men consuming their usual diet for $40 \mathrm{~d}$ (periods 1 and 2 , each of $20 \mathrm{~d}$ )

\begin{tabular}{lccc}
\hline \hline Subject & Initial body-wt & Period $1^{*}$ & Period 2* \\
\hline M1 & $62 \cdot 0$ & $60 \cdot 5$ & $60 \cdot 0$ \\
M2 & $57 \cdot 0$ & $54 \cdot 0$ & $54 \cdot 0$ \\
M3 & $57 \cdot 0$ & $57 \cdot 0$ & $57 \cdot 0$ \\
M4 & $56 \cdot 0$ & $56 \cdot 0$ & $55 \cdot 0$ \\
M5 & $58 \cdot 0$ & $57 \cdot 5$ & $57 \cdot 5$ \\
M6 & $61 \cdot 0$ & $60 \cdot 0$ & $60 \cdot 0$ \\
M7 & $69 \cdot 0$ & $68 \cdot 5$ & $69 \cdot 0$ \\
M8 & $64 \cdot 5$ & $61 \cdot 0$ & $62 \cdot 0$ \\
M9 & $49 \cdot 5$ & $49 \cdot 0$ & $49 \cdot 0$ \\
M10 & $60 \cdot 0$ & $58 \cdot 5$ & $59 \cdot 0$ \\
M11 & $73 \cdot 5$ & $70 \cdot 0$ & $67 \cdot 5$ \\
M12 & $61 \cdot 0$ & $60 \cdot 5$ & $60 \cdot 5$ \\
Mean & $60 \cdot 7$ & $59 \cdot 4$ & $59 \cdot 2 \mathrm{NS}$ \\
SD & $6 \cdot 3$ & $5 \cdot 7$ & $5 \cdot 5$ \\
\hline
\end{tabular}

NS, no significant difference in body-weight $(P>0.05)$.

* Average body-weight of the last $5 \mathrm{~d}$ of each period.

$\mathrm{N}$ balance (Table 4) was calculated with integumentary $\mathrm{N}$ loss measured at $10.4 \mathrm{mg} \mathrm{N} /$ $\mathrm{kg}$ body-weight per $\mathrm{d}$. $\mathrm{N}$ balance for the young men during the two successive $20 \mathrm{~d}$ experimental periods was 6.59 (SD 6.93) and 8.24 (SD 8.61) $\mathrm{mg} \mathrm{N} / \mathrm{kg}$ body-weight respectively. During the last $5 \mathrm{~d}$ of the initial $20 \mathrm{~d}$ period, only two subjects were in negative $\mathrm{N}$ balance. The difference in $\mathrm{N}$ balance between the two periods was not significant. Urinary creatinine (Table 5) measured during the last $5 \mathrm{~d}$ of each $20 \mathrm{~d}$ period was used as an index of the consistency and completeness of urine collections. Generally there was no change in the daily urinary creatinine excretion of the twelve subjects during the two consecutive $20 \mathrm{~d}$ periods. Also the relative contribution of urinary $\mathrm{N}$ to total $\mathrm{N}$ excretion, which was about $80 \%$, was unchanged throughout the study. 
Table 3. Anthropometric measurements of young adult Nigerian males at the beginning, middle and end of the long-term study

(Mean values and standard deviations)

\begin{tabular}{|c|c|c|c|c|c|c|}
\hline \multirow[t]{2}{*}{ Stage of study ... } & \multicolumn{2}{|c|}{ Beginning } & \multicolumn{2}{|c|}{ Middle } & \multicolumn{2}{|c|}{ End } \\
\hline & Mean & SD & Mean & sD & Mean & SD \\
\hline Wt $(\mathrm{kg})$ & $60 \cdot 7$ & $6 \cdot 3$ & $59 \cdot 4$ & $5 \cdot 7$ & $59 \cdot 2 \mathrm{NS}$ & $5 \cdot 5$ \\
\hline Mid-arm muscle circumference (mm)* & $267 \cdot 0$ & $12 \cdot 0$ & $267 \cdot 0$ & $12 \cdot 0$ & $267 \cdot 0 \mathrm{NS}$ & 11 \\
\hline Waist circumference (mm) & $720 \cdot 0$ & $29 \cdot 0$ & $714 \cdot 0$ & $34 \cdot 0$ & $714 \cdot 0 \mathrm{NS}$ & 30 \\
\hline Total skinfold thickness (mm) & $36 \cdot 6$ & $10 \cdot 5$ & 35.9 & $10 \cdot 8$ & $35 \cdot 2 \mathrm{NS}$ & $10 \cdot 6$ \\
\hline Percentage body fat ${ }^{*}$ & $15 \cdot 6$ & $3 \cdot 2$ & $15 \cdot 3$ & 3.4 & $15 \cdot 1 \mathrm{NS}$ & $3 \cdot 3$ \\
\hline
\end{tabular}

NS, not significantly different $(P>0.05)$ from the values at the beginning of the study.

* Calculated after the method of Gurney \& Jellifie (1973).

Table 4. Nitrogen balance ( $\mathrm{mg} / \mathrm{kg}$ per $d$ ) of twelve adult Nigerian males consuming their usual diet for $40 \mathrm{~d}$ (periods 1 and 2 , each of $20 \mathrm{~d}$ )

\begin{tabular}{|c|c|c|c|c|c|}
\hline Subject & NI & UN & FN & $\mathrm{TN}$ & $\mathrm{N}$ balance \\
\hline \multicolumn{6}{|c|}{ Period 1} \\
\hline M1 & $119 \cdot 1$ & 84.0 & $15 \cdot 8$ & $110 \cdot 13$ & 8.95 \\
\hline M2 & 131.6 & 87.7 & 21.8 & 119.95 & 11.60 \\
\hline M3 & $128 \cdot 1$ & $88 \cdot 2$ & $13 \cdot 3$ & 111.87 & $16 \cdot 18$ \\
\hline M4 & $130 \cdot 4$ & $85 \cdot 2$ & $29 \cdot 1$ & $124 \cdot 78$ & $5 \cdot 58$ \\
\hline M5 & 125.8 & $81 \cdot 7$ & $31 \cdot 0$ & 123.07 & $2 \cdot 38$ \\
\hline M6 & 119.6 & $85 \cdot 3$ & $26 \cdot 3$ & 121.97 & $-2 \cdot 38$ \\
\hline M7 & $104 \cdot 0$ & 75.8 & $15 \cdot 2$ & $101 \cdot 43$ & 3.43 \\
\hline M8 & 116.7 & $78 \cdot 1$ & $25 \cdot 7$ & $114 \cdot 27$ & $2 \cdot 42$ \\
\hline M9 & $147 \cdot 7$ & 87.8 & $32 \cdot 4$ & $130 \cdot 42$ & $17 \cdot 13$ \\
\hline M10 & $122 \cdot 6$ & $74 \cdot 5$ & $30 \cdot 0$ & 114.93 & $7 \cdot 70$ \\
\hline $\mathbf{M} 11$ & $102 \cdot 0$ & 73.0 & $24 \cdot 1$ & $107 \cdot 46$ & $-5 \cdot 56$ \\
\hline M12 & 118.6 & 83.0 & 13.9 & $107 \cdot 34$ & $11 \cdot 27$ \\
\hline Mean & $122 \cdot 23$ & $82 \cdot 02$ & $23 \cdot 22$ & 115.64 & 6.59 \\
\hline SD & $12 \cdot 14$ & $5 \cdot 40$ & 7.06 & $8 \cdot 55$ & 6.93 \\
\hline \multicolumn{6}{|c|}{ Period 2} \\
\hline $\mathrm{Ml}$ & $120 \cdot 58$ & 84.69 & $20 \cdot 36$ & 115.45 & $5 \cdot 13$ \\
\hline $\mathrm{M} 2$ & 133.98 & $81 \cdot 68$ & $20 \cdot 65$ & 112.73 & $21 \cdot 25$ \\
\hline M3 & 125.83 & 85.07 & 15.03 & $116 \cdot 11$ & $9 \cdot 72$ \\
\hline M4 & 131.55 & $88 \cdot 79$ & $27 \cdot 34$ & $121 \cdot 51$ & 10.04 \\
\hline M5 & 124.74 & $82 \cdot 62$ & $30 \cdot 40$ & $123 \cdot 42$ & 1.32 \\
\hline M6 & $120 \cdot 58$ & $79 \cdot 71$ & $29 \cdot 56$ & 119.67 & 0.91 \\
\hline M7 & $104 \cdot 86$ & $74 \cdot 80$ & $14 \cdot 36$ & 99.56 & $5 \cdot 30$ \\
\hline M8 & 116.96 & 83.57 & $24 \cdot 39$ & $118 \cdot 36$ & -1.67 \\
\hline M9 & 147.65 & $86 \cdot 33$ & 26.98 & $123 \cdot 70$ & 23.95 \\
\hline M10 & 122.63 & $75 \cdot 80$ & $30 \cdot 58$ & 106.77 & 15.86 \\
\hline M11 & $106 \cdot 40$ & 74.49 & 23.05 & 108.94 & -2.54 \\
\hline M12 & $118 \cdot 61$ & 85.64 & $12 \cdot 93$ & $108 \cdot 97$ & $9 \cdot 64$ \\
\hline Mean & 122.84 & 81.93 & 22.97 & $114 \cdot 60$ & $8 \cdot 24$ \\
\hline SD & 11.63 & 4.76 & $6 \cdot 35$ & $7 \cdot 42$ & 8.61 \\
\hline
\end{tabular}

NI, nitrogen intake; UN, urinary $N$; FN, faecal N; TN, total N including integumentary $N$ losses measured at $10.4 \mathrm{mg} \mathrm{N} / \mathrm{kg}$ per $\mathrm{d}$. 
Table 5. Urinary creatinine excretion $(\mathrm{mg} / \mathrm{kg}$ per $\mathrm{d}$ ) of twelve adult Nigerian men consuming their usual diet for $40 d$ (periods 1 and 2, each of $20 d)^{*}$

(Mean values and standard deviations)

\begin{tabular}{|c|c|c|c|c|}
\hline \multirow[b]{2}{*}{ Subject } & \multicolumn{2}{|c|}{ Period I } & \multicolumn{2}{|c|}{ Period 2} \\
\hline & Mean & SD & Mean & SD \\
\hline M1 & $27 \cdot 24$ & $0 \cdot 30$ & $27 \cdot 32$ & 0.98 \\
\hline M2 & 25.00 & 0.90 & $24 \cdot 44$ & 0.24 \\
\hline M3 & $22 \cdot 42$ & 0.47 & $23 \cdot 22$ & 0.29 \\
\hline M4 & $25 \cdot 50$ & 0.36 & $25 \cdot 47$ & 0.28 \\
\hline M5 & $25 \cdot 40$ & 0.28 & $25-42$ & 0.28 \\
\hline M6 & $27 \cdot 19$ & 0.40 & $27 \cdot 57$ & 0.13 \\
\hline M7 & 27.94 & 0.59 & $28 \cdot 35$ & $0 \cdot 29$ \\
\hline M8 & 26.94 & 0.28 & $26 \cdot 26$ & 0.31 \\
\hline M9 & $20 \cdot 55$ & 0.15 & $20 \cdot 05$ & 0.18 \\
\hline M10 & 22.97 & 0.22 & 23.45 & 0.63 \\
\hline M11 & $30 \cdot 28$ & $0 \cdot 18$ & 29.80 & 0.58 \\
\hline M12 & 26.69 & 0.09 & $26 \cdot 72$ & 0.17 \\
\hline All subjects & $25 \cdot 62$ & $2 \cdot 65$ & $25 \cdot 60 \mathrm{NS}$ & 2.65 \\
\hline
\end{tabular}

NS, not significantly different from period $1(P>0.05)$.

* Average of the last $5 \mathrm{~d}$ of each period.

Table 6. Mean nitrogen intake, faecal $N$, apparent $N$ absorbed ( $m g / k g$ body-weight per $d)$ and protein quality indices of habitual diets consumed by twelve adult Nigerian men for $40 \mathrm{~d}$ ( periods 1 and 2, each of $20 \mathrm{~d}$ )

(Mean values and standard deviations)

\begin{tabular}{lrccrrrr}
\hline Period & N intake & Faecal N & $\begin{array}{c}\text { Apparent } \\
\text { N absorbed }\end{array}$ & $\begin{array}{c}\text { Apparent } \\
\text { digestibility }\end{array}$ & TD & BV & NPU \\
\hline I Mean & 122.23 & 23.22 & 99.01 & 81.04 & 96.16 & 64.01 & 61.59 \\
SD & 12.14 & 7.06 & $11 \cdot 19$ & 5.29 & 5.58 & 2.68 & 4.91 \\
2 Mean & 122.84 & 22.97 & 99.82 & 81.04 & 97.35 & 65.58 & 63.11 \\
SD & 11.63 & 6.35 & 11.18 & 4.94 & 5.19 & 4.44 & 4.69 \\
\hline
\end{tabular}

NS, not significantly different from values in group $1(P>0.05)$; TD, true digestibility; BV, biological value; NPU, net protein utilization.

Faecal output also did not show any significant changes with time. Table 6 shows the apparent $\mathbf{N}$ absorbed as well as $\mathbf{N}$ digestibility. For the first and second experimental periods, digestibility was calculated to be 81.04 and $81.31 \%$ respectively.

\section{Protein quality}

The protein quality indices of the diets are shown in Table 7. The biological value (BV) and net protein utilization (NPU) were calculated by the conventional methods using the obligatory $\mathrm{N}$ loss values of $69.23 \mathrm{mg} \mathrm{N} / \mathrm{kg}$ body-weight per $\mathrm{d}$ as obtained from a previous study by Atinmo et al. (1985).

The digestibility values for periods 1 and 2 were 96.16 and $96.35 \%$ respectively. NPU and BV values also showed no significant changes with time. BV and NPU values were 65 and $62 \%$ respectively. 
Table 7. Protein quality indices of habitual diets consumed by twelve adult Nigerian men for $40 \mathrm{~d}$ (periods 1 and 2, each of $20 \mathrm{~d}$ )

(Mean values and standard deviations)

\begin{tabular}{|c|c|c|c|c|}
\hline \multirow[b]{2}{*}{ Indices } & \multicolumn{2}{|c|}{ Period 1} & \multicolumn{2}{|c|}{ Period 2} \\
\hline & Mean & SD & Mean & SD \\
\hline $\begin{array}{l}\text { True digestibility } \\
\text { Biological value } \\
\text { Net protein utilization }\end{array}$ & $\begin{array}{l}96 \cdot 16 \\
64 \cdot 03 \\
61 \cdot 59\end{array}$ & $\begin{array}{l}5 \cdot 58 \\
2 \cdot 68 \\
4 \cdot 91\end{array}$ & $\begin{array}{l}96 \cdot 35^{*} \\
65 \cdot 58^{*} \\
63 \cdot 11^{*}\end{array}$ & $\begin{array}{l}5 \cdot 19 \\
4 \cdot 44 \\
4 \cdot 69\end{array}$ \\
\hline
\end{tabular}

Significantly different from period $1 .{ }^{*} P<0.05$

Table 8. Effect of protein intake at $0.75 \mathrm{~g} / \mathrm{kg}$ per $\mathrm{d}$ for $40 \mathrm{~d}$ on various blood biochemical indices in twelve young adult male Nigerians

(Mean values and standard deviations)

\begin{tabular}{|c|c|c|c|c|c|c|c|}
\hline & \multicolumn{2}{|c|}{ Initial } & \multicolumn{2}{|c|}{ Period $1,20 \mathrm{~d}$} & \multicolumn{2}{|c|}{ Period 2, $20 \mathrm{~d}$} & \multirow[b]{2}{*}{$F$} \\
\hline & Mean & SD & Mean & SD & Mean & SD & \\
\hline Packed cell volume & 0.48 & 0.026 & 0.47 & 0.032 & 0.47 & 0.032 & $0.537^{*}$ \\
\hline Haemoglobin $(\mathrm{g} / \mathrm{l})$ & $15 \cdot 70$ & $2 \cdot 12$ & $15 \cdot 58$ & $1 \cdot 10$ & $16 \cdot 35$ & 1.22 & $0.846^{*}$ \\
\hline Blood sugar (mg/l) & 836 & 112 & 817 & 81 & 816 & 90 & $0.175^{*}$ \\
\hline Total protein $(\mathrm{g} / 1)$ & 74 & 5.9 & 71 & $5 \cdot 1$ & 72 & 5.0 & $0.764^{*}$ \\
\hline Albumin $(\mathrm{g} / \mathrm{l})$ & 41 & $4 \cdot 8$ & 38 & $5 \cdot 2$ & 38 & $4 \cdot 1$ & $1.788^{*}$ \\
\hline Urea N (mg/l) & 154 & $17 \cdot 5$ & 142 & $20 \cdot 4$ & 139 & $2 \cdot 3$ & $1.840^{*}$ \\
\hline Creatinine (mg/l) & 16 & $2 \cdot 9$ & 15 & $2 \cdot 7$ & 15 & $2 \cdot 9$ & $0.464^{*}$ \\
\hline Cholesterol (mg/l) & 1438 & $173 \cdot 6$ & 1388 & $167 \cdot 3$ & 1412 & 160 & $0.272^{*}$ \\
\hline GPT (U/1) & 10.04 & 1.99 & 12.57 & 3.67 & $12 \cdot 00$ & $3 \cdot 36$ & $2 \cdot 184^{*}$ \\
\hline GOT $(\mathrm{U} / \mathrm{l})$ & 12.93 & $1 \cdot 82$ & 16.04 & $4 \cdot 36$ & $15 \cdot 20$ & $3 \cdot 73$ & $2.576^{*}$ \\
\hline
\end{tabular}

GPT, Alanine amino transferase; GOT, Aspartate amino transferase.

$F$, from analysis of variance; $*>0.05$.

\section{Biochemical variables}

The blood biochemical variables analysed are shown in Table 8 . Statistical analysis of all variables did not reveal any significant changes with time $(P>0.05)$. However, there were some individual variations in certain blood variables. Blood urea- $N$ was greater during the initial baseline period than during subsequent periods. The activities of the transaminases, serum alanine aminotransferase $(E C$ 2.6.1.2) and aspartate aminotransferase (EC 2.6.1.1), were relatively higher on the introduction of the diet but were reduced with time. The increase in the activities of transaminases could be accounted for by subjects M6 and M11 who were in negative $\mathrm{N}$ balance.

Packed cell volume, haemoglobin, blood sugar, total protein, albumin, creatinine and cholesterol levels showed no significant changes.

\section{DISCUSSION}

The present investigation was not designed to determine the minimum protein requirement for the adult male Nigerian, since only one level of protein intake was tested, but rather to ascertain the adequacy of the previously estimated safe intake level of $0.75 \mathrm{~g}$ protein $/ \mathrm{kg}$ 
body-weight (Atinmo et al. 1981, 1988) with energy intake fixed at $0.2 \mathrm{MJ} / \mathrm{kg}$ body-weight per $\mathrm{d}$. Although slight adjustments were made in the level of energy intake of some of the subjects during the first experimental period, body-weight showed no significant changes, suggesting that energy intake was adequate during the study.

Urinary excretion did not fluctuate much with time. In fact, there was stability in the urinary $\mathrm{N}$ excretion after an initial fall during the first $6 \mathrm{~d}$ of the experimental period. Subsequent variations were assumed to be due mainly to random and biological variations (Rand et al. 1979). Urinary creatinine level was used as an index of the consistency and completeness of urine collections as well as an indicator of skeletal musculature (Young, 1970). Since the creatinine levels observed in the present study did not show any significant changes, it may be said that no significant losses occurred in muscle or body mass of the subjects, thus implying an adequate adaptation to the level of protein in the diet.

Some of the principal difficulties commonly encountered in the interpretation of $\mathrm{N}$ balance values have centred around the uncertainties in estimating skin and miscellaneous N losses (Isaksson \& Sjorgren, 1967; Calloway et al. 1971) and on the likelihood of overestimating actual intakes and underestimating total $\mathrm{N}$ losses (Wallace, 1959). The cumulative errors that follow are likely to result in an overestimation of $\mathbf{N}$ retention. With this background, special attention was paid to the measuring of $\mathrm{N}$ losses and to the estimation of $N$ in sweat. The $N$ loss through this route was higher $(10.4 \mathrm{mg} \mathrm{N} / \mathrm{kg}$ bodyweight per d) than the value estimated by Atinmo et al. (1985) as obligatory $\mathrm{N}$ losses in adult Nigerian men. In our opinion, the difference in values from those of Atinmo et al. (1985) is most likely to be due to the higher $\mathrm{N}$ intake by subjects in the present study. According to Cuthbertson \& Guthrie (1934), an increase in $\mathrm{N}$ intake results in a corresponding increase in $\mathrm{N}$ excretion through sweat.

Faecal $N$ output remained essentially the same throughout the course of the experiment. Faecal $\mathrm{N}$ can be affected by the composition or quality of the diet (Southgate, 1982). In the present study, the quality and digestibilities (apparent and true) of the protein given were high (81 and $95 \%$ for apparent and true digestibilities respectively). In addition, the BV and NPU were 65 and 62 respectively compared with those of egg protein (Huang \& Lin, 1982).

The mean $\mathrm{N}$ balance was positive during both experimental periods. All the participants, except two, exhibited positive $\mathrm{N}$ balance. One of the two subjects, M11, lost weight by the end of the first experimental period. This was clearly reflected by a negative $\mathrm{N}$ balance and also raised levels of aspartate aminotransferase and alanine aminotransaminases. The energy intake of this subject was adjusted accordingly and by the end of the second experimental period there were considerable changes, but not enough to enable the subject to attain a positive $\mathrm{N}$ balance. The positive $\mathrm{N}$ balance exhibited by the other subjects during the two experimental periods did not differ significantly. It is not, however, possible to determine from our findings, whether the observed positive $\mathrm{N}$ balance could drift to zero balance with time, as theoretically, for adults, once $\mathrm{N}$ requirements are met an excess $\mathrm{N}$ intake would normally cause a positive balance and finally, within a short period of time, return to zero balance. Reports by Oddoye \& Margen (1979) from experiments in which they gave $36 \mathrm{~g}$ protein/d to six healthy young adults, however, showed no significant trend towards such an adaptation.

The difficulties and discrepancies associated with the $\mathrm{N}$ balance method have caused many investigators to question its validity as the only criterion for estimating the amount of $\mathrm{N}$ which is necessary to maintain an individual in optimal health. Yoshimura (1972) has therefore suggested the use of other additional physiological indices. In the present study increases in concentrations of serum amino transferases (alanine and aspartate) were observed in the first experimental period and a closer look at the values showed that this 
was due mainly to the two subjects who had gone into negative $\mathrm{N}$ balance. The levels, however, fell with time and with an adjustment in the level of energy intake. All other measurements of packed cell volume, haemoglobin, blood sugar, total plasma protein, albumin, urea, creatinine and cholesterol were within normal limits and showed no significant changes with time.

The findings obtained from the present study point to the conclusion that a protein intake of $0.75 \mathrm{~g} / \mathrm{kg}$ body-weight per d with an energy intake of $0.2 \mathrm{MJ} / \mathrm{kg}$ body-weight per $d$ was sufficient to maintain most of the subjects in positive $\mathrm{N}$ balance $(+8 \cdot 2 \mathrm{mg} \mathrm{N} / \mathrm{kg}$ body-weight per d) under normal physiological conditions. This observation therefore clearly confirms earlier studies in adults, as well as in young adult Nigerian males by Atinmo et al. (1988).

\section{REFERENCES}

Atinmo, T., Egun, G. \& Mbofung, C. M. F. (1988). British Journal of Nutrition 60, 451-458.

Atinmo, T., Hussain, M. A., Palmer, F. O. \& Osotimehin, B. O. (1981). Nigerian Journal of Nutritional Sciences 2, $129-130$.

Atinmo, T., Mbofung, C. M. F., Hussain, M. A. \& Osotimehin, B. O. (1985). British Journal of Nutrition 54, 605-611.

Calloway, D. M., Odel, A. C. \& Margen, S. (1971). Journal of Nutrition 101, 775-786.

Cuthbertson, D. P. \& Guthrie, W. S. W. (1934). Biochemistry Journal 28, 1444-1453.

Gurney, M. \& Jelliffe, D. B. (1973). American Journal of Clinical Nutrition 26, 912-917.

Huang, P. C. \& Lin, C. P. (1982). Journal of Nutrition 112, 897-907.

Isaksson, B. \& Sjorgren, B. (1967). Proceedings of the Nutrition Society 26, 106-124.

Oddoye, E. A. \& Margen, S. (1979). Journal of Nutrition 109, 363-377.

Rand, W. M., Scrimshaw, N. S. \& Young, V. R. (1979). American Journal of Clinical Nutrition 32, 1408-1414.

Scrimshaw, N. S., Hussein, M. A., Murray, E., Rand, W. M. \& Young, V. R. (1972). Journal of Nutrition 102, 1595-1604.

Sirbu, E. R., Margen, S. \& Calloway, D. H. (1967). American Journal of Clinical Nutrition 20, 1158-1165.

Southgate, D. A. T. (1982). In Dietary Fiber in Health and Disease, pp. 45-52 [G. Y. Vahouny and D. Kritchvevsky, editors]. New York: Plenum Press.

Spence, N. P., Mbernathy, R. P. \& Ritchery, S. J. (1972). American Journal of Clinical Nutrition 25, $275-278$.

Wallace, W. M. (1959). Federation Proceedings 18, $1125-1130$.

World Health Organization (1973). Technical Report Series, no. 522. Geneva: WHO.

Yoshimura, H. (1972). World Review of Nutritional Science 2, 129-139.

Young, V. R. (1970). In Mammalian Protein Metabolism, vol. 4, pp. 585-674 [H. N. Munro, editor]. New York: Academic Press. 